\title{
Cleavage of cytoskeletal proteins by caspases during ovarian cell death: evidence that cell-free systems do not always mimic apoptotic events in intact cells
}

\author{
Daniel V. Maravei ${ }^{1}$, Alexander M. Trbovich ${ }^{1}$, Gloria I. Perez ${ }^{1}$, \\ Kim I. Tilly ${ }^{1}$, David Banach ${ }^{2}$, Robert V. Talanian ${ }^{2}$, \\ Winnie W. Wong ${ }^{2}$ and Jonathan L. Tilly ${ }^{1,3}$

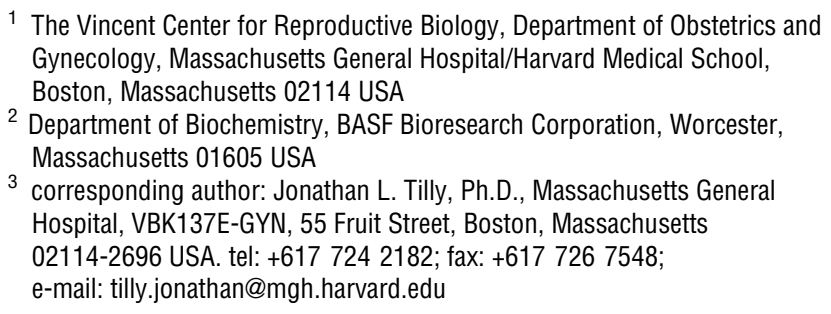

Received 28.1.97; revised 24.4.97; accepted 14.7.97 Edited by J.C. Reed

\begin{abstract}
Several lines of evidence support a role for protease activation during apoptosis. Herein, we investigated the involvement of several members of the CASP (cysteine aspartic acid-specific protease; CED-3- or ICE-like protease) gene family in fodrin and actin cleavage using mouse ovarian cells and HeLa cells combined with immunoblot analysis. Hormone deprivation-induced apoptosis in granulosa cells of mouse antral follicles incubated for $24 \mathrm{~h}$ was attenuated by two specific peptide inhibitors of caspases, zVAD-FMK and ZDEVD-FMK (50-500 $\mu \mathrm{M})$, confirming that these enzymes are involved in this paradigm of cell death. Proteolysis of actin was not observed in follicles incubated in vitro while fodrin was cleaved to the $120 \mathrm{kDa}$ fragment that accompanies apoptosis. Fodrin, but not actin, cleavage was also detected in HeLa cells treated with various apoptotic stimuli. These findings suggest that, in contrast to recent data, proteolysis of cytoplasmic actin may not be a component of the cell death cascade. To confirm and extend these data, total cell proteins collected from mouse ovaries or non-apoptotic HeLa cells were incubated without and with recombinant caspase-1 (ICE), caspase-2 (ICH-1) or caspase-3 (CPP32). Immunoblot analysis revealed that caspase-3, but not caspase-1 nor caspase-2, cleaved fodrin to a $120 \mathrm{kDa}$ fragment, wheres both caspases-1 and -3 (but not caspase-2) cleaved actin. We conclude that CASP gene family members participate in granulosa cell apoptosis during ovarian follicular atresia, and that collapse of the granulosa cell cytoskeleton may result from caspase-3catalyzed fodrin proteolysis. However, the discrepancy in the data obtained using intact cells (actin not cleaved)
\end{abstract}

versus the cell-free extract assays (actin cleaved) raises concern over previous conclusions drawn related to the role of actin cleavage in apoptosis.

Keywords: apoptosis; caspase; ICE; CPP32; actin; fodrin; proteolysis; granulosa cell; follicle; atresia

\begin{abstract}
Abbreviations: caspase, cysteine aspartic acid-specific protease (CASP, designation of the gene); ICE, interleukin$1 \beta$-converting enzyme; zVAD-FMK, benzyloxycarbonyl-ValAla-Asp-fluoromethylketone; zDEVD-FMK, benzyloxycarbonyl-Asp-Glu-Val-Asp-fluoromethylketone; kDa, kilodaltons; $\mathrm{ICH}-1$, ICE/CED-3 homolog-1; CPP32, cysteine protease p32; PARP, poly(ADP-ribose)-polymerase; MW, molecular weight; STSP, staurosporine; C8-CER, C8-ceramide; DTT, dithiothrietol; $C C G$, equine chorionic gonadotropin (PMSG or pregnant mare's serum gonadotropin); ddATP, dideoxy-ATP; $\mathrm{kb}$, kilobases; HEPES, N-(2-hydroxyethyl)piperazine- $\mathrm{N}^{\prime}-(2-$ ethanesulfonic acid); SDS-PAGE, sodium dodecylsulfatepolyacrylamide gel electrophoresis; ANOVA, analysis of variance
\end{abstract}

\section{Introduction}

Physiological cell death is a process that has been identified to occur in many cell types and, when deregulated, may be an underlying mechanism by which tissues reach a pathological or diseased state (Thompson, 1995). Much of the work in this field has been directed towards identifying the components of the cell death machinery that carry out 'the order' to initiate apoptosis. These data suggest that activation of a cascade of intracellular proteases may be integral to this event, the endresult of which leads to the demise of the cell (Yuan et al, 1993; Martin and Green, 1995; Kumar and Lavin, 1996; Patel et al, 1996). Central to the study of proteases and apoptosis is work that has focused on the identification of vertebrate homologs of the ced-3 gene product required for programmed cell death in the nematode, Caenorhabditis elegans (Ellis and Horvitz, 1986; Yuan et al, 1993; Xue et al, 1996). To date, at least 11 CED-3 homologs have been identified in vertebrates, and for the sake of clarity these enzymes are now being collectively termed cysteine aspartic acid-specific proteases (caspases; Alnemri et al, 1996). All members of the caspase family in vertebrates, including caspase-1 (interleukin-1 $\beta$ converting enzyme or ICE), caspase-2 (NEDD-2 or ICH-1) and caspase-3 (CPP32, Yama or apopain) studied herein, share two unique features: a consensus pentapeptide domain (QACXG) containing the cysteine active site, and obligate specificity for cleavage of target proteins at aspartate residues (Martin and Green, 1995; Patel et al, 1996; Kumar and Lavin, 1996). 
With the recent purification of many of these proteases, several key protein substrates cleaved by members of the CASP gene family have been identified. For example, in addition to processing pro-IL $1 \beta$ and pro-caspase- 1 to their active forms, caspase- 1 also activates pro-caspase-3. More recently, caspase-1 was reported to cleave actin in a cellfree system, as well as in intact cells during death (Mashima et al, 1995; Kayalar et al, 1996), possibly as a means to liberate or activate DNase-I (Kayalar et al, 1996). In addition to actin, other homeostatic proteins are subject to proteolysis by caspases. These include a second cytoskeletal protein (fodrin; Martin et al, 1995, 1996), as well as nuclear-associated proteins such as poly(ADPribose) polymerase (PARP), the $\mathrm{U} 1-70 \mathrm{kDa}$ protein component of small nuclear ribonucleoproteins, the catalytic subunit of DNA-dependent protein kinase, and lamins (Martin and Green, 1995; Patel et al, 1996; Casciola-Rosen et al, 1996).

Despite these advances in our understanding of the role of proteases in apoptosis, there are limitations in the interpretation of the data, particularly those findings related to cleavage of cytoskeletal proteins. For example, caspase1-deficient mice do not exhibit defects in many instances of apoptosis (glucocorticoid-treated thymus gland, post-weaning mammary gland) (Kuida et al, 1995; Li et al, 1995), suggesting that either caspase-1-mediated actin cleavage is not required for apoptosis or that an enzyme other than caspase- 1 is involved in actin proteolysis. Moreover, data to support the role of actin cleavage during apoptosis are for the most part inconclusive due to the extrapolation of results obtained primarily from cell-free assays to the in vivo situation (Mashima et al, 1995; Kayalar et al, 1996). Data that implicate fodrin proteolysis in apoptosis are more convincing, although several questions remain concerning the identity of the protease(s) responsible for cleavage of this protein (Martin et al, 1995, 1996). Thus, we used a combination of intact cell and cell-free systems to elucidate if cleavage of actin or fodrin is observed during apoptosis under diverse conditions, and to identify enzyme(s) capable of cleaving these two cytoskeletal proteins.

\section{Results and Discussion}

The intracellular effectors involved in the initiation, progression and completion of apoptosis are believed to be conserved across most species and cell types (Korsmeyer, 1995; Wyllie, 1995). In agreement with this proposal, results from recent studies suggest that apoptotic death of granulosa cells during ovarian follicular atresia is likely dependent upon the actions and interactions of a number of these conserved regulatory factors (reviewed in Tilly, 1996; Tilly and Ratts, 1996; Tilly et al, 1997), including members of the CASP gene family (Flaws et al, 1995a). Consistent with previous findings from other cell types (Patel et al, 1996; Cain et al, 1996; Jacobson et al, 1996), the occurrence of apoptosis in serumdeprived follicles incubated in vitro was attenuated by either of two specific peptide inhibitors of caspases (Figure 1). At the highest concentration tested $(500 \mu \mathrm{M})$, zVAD-FMK and zDEVD-FMK reduced the levels of low MW DNA labeling, a measure of the extent of apoptosis (see Materials and
Methods) to $39 \pm 5 \%$ and $44 \pm 10 \%$, respectively, of those levels detected in serum-deprived follicles incubated for $24 \mathrm{~h}$ with vehicle alone $(P<0.05$ for each, $n=5)$.

Based on these data that further support a functional role for caspases in granulosa cell death, we next determined if two cytoskeletal elements known to be cleaved by caspases are targeted for destruction during atresia. Immunoblot analysis of actin in total proteins extracted from follicles prior to ( $0 \mathrm{~h}$; no apoptosis) and after a $48 \mathrm{~h}$ serum-free incubation (extensive apoptosis) revealed no evidence of cleavage of the $42 \mathrm{kDa}$ intact form (Figure 2A), contrasting the pattern of actin fragments generated by caspase- 1 or caspase-3 attack using a cellfree approach (Figure 3) (Kayalar et al, 1996). Similarly, treatment of follicles with staurosporine (STSP), a protein kinase inhibitor that activates apoptosis in essentially all eukaryotic cell systems (Weil et al, 1996), further increased apoptosis in serum-starved follicles (data not shown) but did not induce cleavage of actin (Figure 2A).

By comparison, immunoblot analysis of fodrin integrity indicated that follicles induced to undergo atresia in vitro by trophic hormone-deprivation exhibited cleavage of the $240 \mathrm{kDa}$ intact form of fodrin to a $120 \mathrm{kDa}$ fragment (Figure 4A). Moreover, STSP treatment caused a further increase in the amount of the $120 \mathrm{kDa}$ fragment generated over that observed in serum-free follicles incubated for $48 \mathrm{~h}$ in medium alone (Figure 4A). Importantly, this cytoskeletal element was cleaved in the same protein preparations that clearly displayed a lack of actin proteolysis (Figure 4 versus Figure 2, respectively), despite the fact that actin is known to be a substrate for caspase-1 (Kayalar et al, 1996).

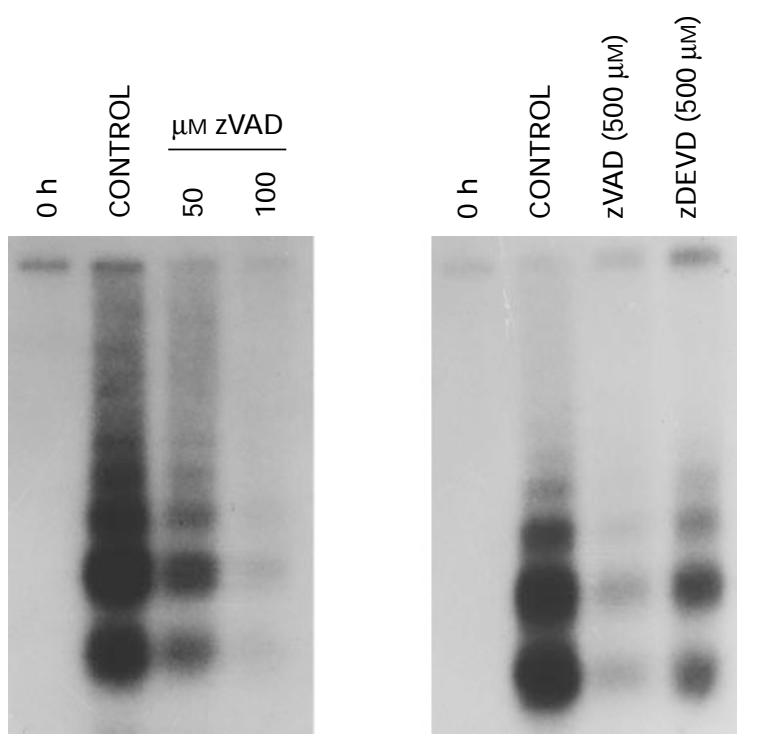

Figure 1 Suppression of apoptosis by specific peptide inhibitors of caspases in mouse ovarian follicles deprived of trophic hormone support in vitro. Healthy antral follicles isolated from ovaries of eCG-primed immature mice were snapfrozen immediately $(0 \mathrm{~h})$ or were incubated for $24 \mathrm{~h}$ without serum in the absence (CONTROL) or presence of ZVAD-FMK $(50-500 \mu \mathrm{M}$, left and right panels) or zDEVD-FMK (500 $\mu \mathrm{M}$, right panel). Genomic DNA was extracted, radiolabeled, resolved by agarose gel electrophoresis, and analyzed by autoradiography for internucleosomal cleavage (DNA 'ladders') characteristic of cells undergoing apoptosis (representative of 5 replicate experiments) 
Based on our recent observations that caspase-1, per se, is likely not a participant in granulosa cell death during follicular atresia in the rodent ovary (Flaws et al, 1995a), these observations were first taken as further evidence that caspase-1 is not involved in this specific paradigm of apoptosis. However, a comparative analysis of actin and
A

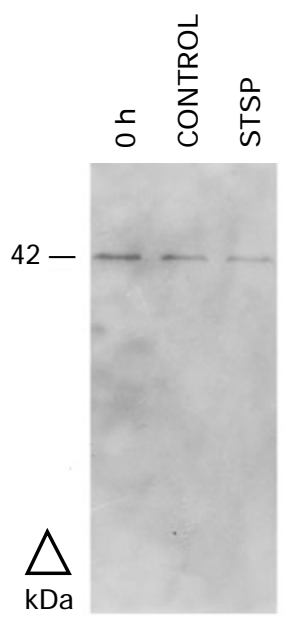

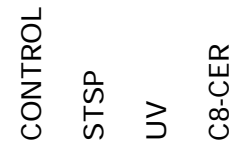

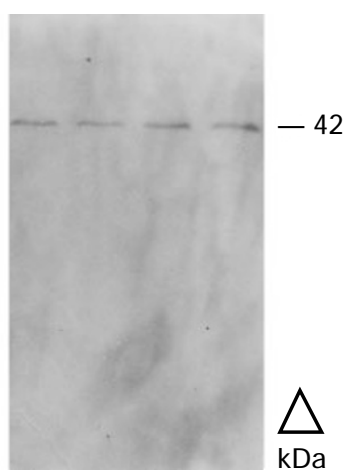

Figure 2 Actin integrity during apoptosis in mouse follicles and HeLa cells. (A) Follicles were frozen $(0 \mathrm{~h})$ or incubated without serum for, $48 \mathrm{~h}$ without (CONTROL) or with staurosporine (STSP), after which total proteins were extracted and analyzed for actin cleavage by immunoblot analysis. (B) For comparison, actin integrity was also assessed in total proteins prepared from HeLa cells following massive apoptosis induced by STSP, UV-irradiation or a ceramide analog (C8-CER) (representative of 3 independent experiments) fodrin integrity in HeLa cells under three different experimental conditions that produce extensive apoptosis (UV-irradiation, or treatment with staurosporine or ceramide) yielded a similar set of results (Figures $2 B$ and $4 B$ ). In addition, apoptosis in HeLa cells triggered by serum starvation, an approach used in a recent report of caspase1-mediated actin cleavage in PC12 cells (Kayalar et al, 1996), similarly proceeded in the absence of actin proteolysis (data not shown). Since HeLa cells express
A

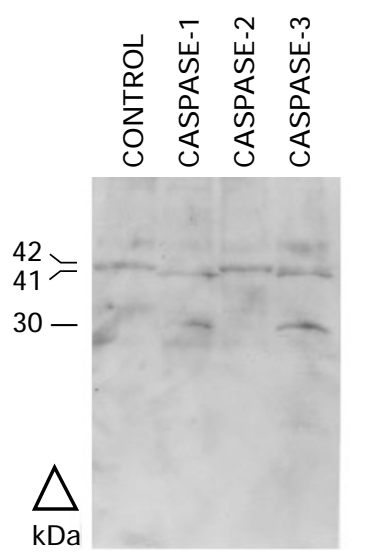

B

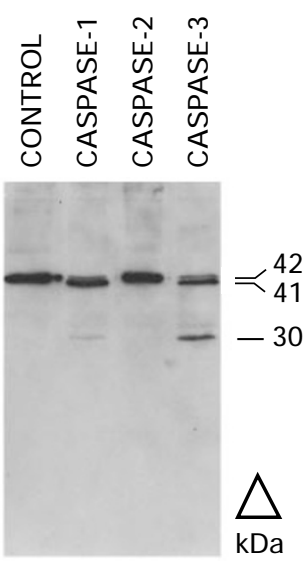

Figure 3 Catalysis of actin cleavage by recombinant caspases in cell-free assays. Total proteins extracted from mouse ovaries $(\mathbf{A})$ or HeLa cells $(\mathbf{B})$ were incubated without (Control) or with caspase-1, caspase-2 or caspase-3, after which immunoblot analysis of actin integrity was conducted (these data are representative of results obtained in at least 3 independent experiments)
A

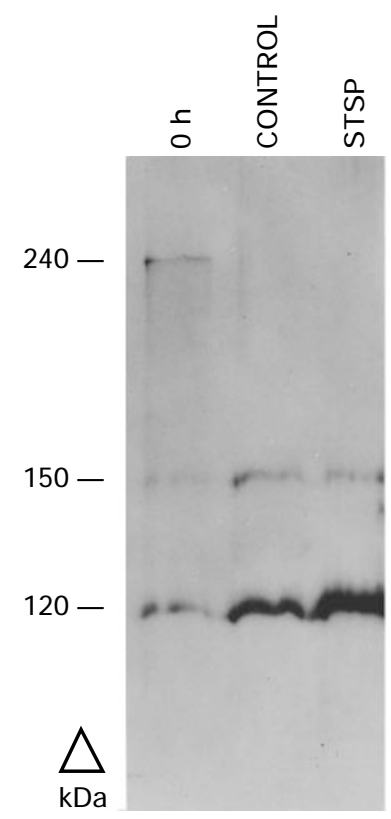

B

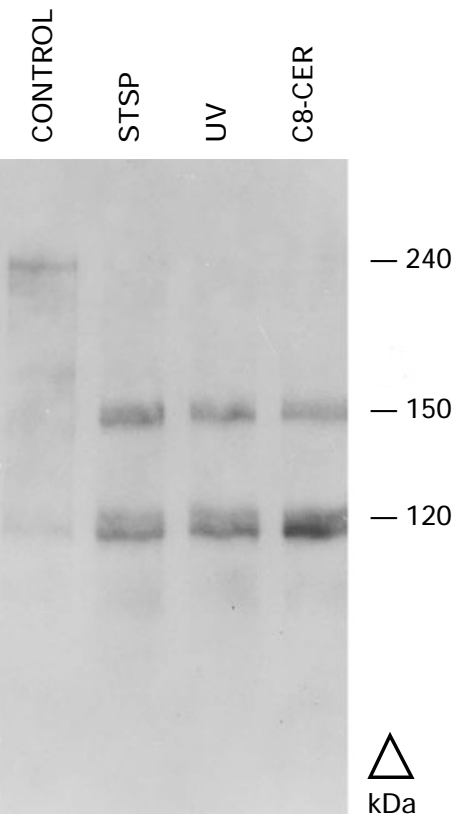

Figure 4 Analysis of fodrin proteolysis during cell death. Using the same protein preparations analyzed in Figure 2, cleavage of fodrin was assessed by immunoblot analysis in mouse follicles $(\mathbf{A})$ or in HeLa cells $(\mathbf{B})$ prior to and following the induction of apoptosis. The culture conditions are as described in the legend to Figure 2, and these blots are representative of data obtained in 3 independent experiments 
A

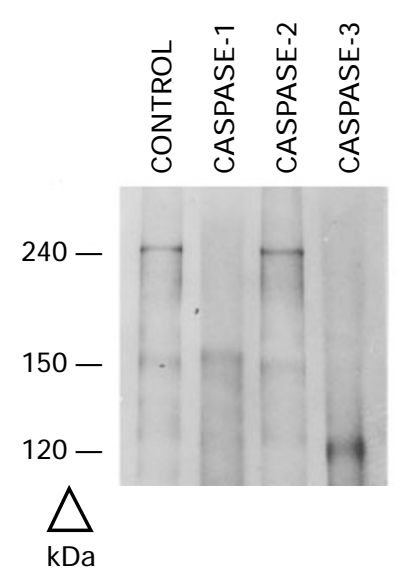

B

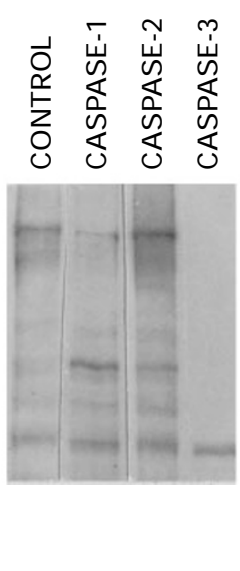

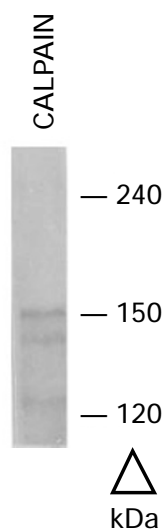

C

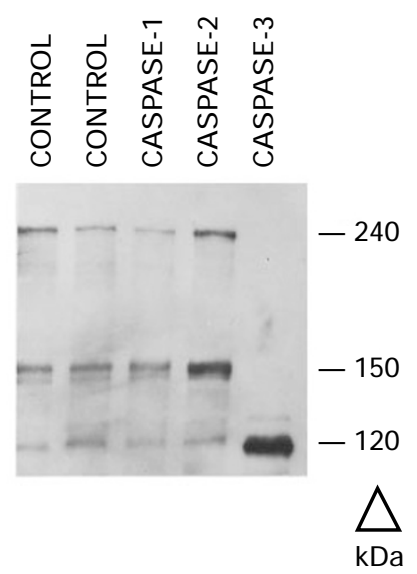

Figure 5 Cleavage of fodrin in cell-free assays by caspases and calpain. Total cell proteins prepared from mouse ovaries (A) or HeLa cells (B) as described in legend to Figure 3 , as well as from rat ovarian granulosa cells (C), were incubated without (CONTROL) or with recombinant caspases, and fodrin proteolysis was assessed by immunoblot analysis. Based on recent data implicating calpain as one possible mediator of fodrin cleavage during cell death (Martin et al, 1995), the pattern of fodrin proteolysis obtained with recombinant caspases was also compared to that generated by calpain in HeLa cell extracts (B). The blots shown are representative of data obtained in at least 3 independent experiments

abundant levels of caspase- 1 and related enzymes (Wang et al, 1994; Friedlander et al, 1996), these data argue that cleavage of actin by caspase-1 (or other proteases) is not an event required for, or even correlated with, apoptosis.

To confirm the specificity and sensitivity of this approach for monitoring proteolysis during cell death, we next used recombinant or purified enzymes in a cell-free assay, as described in recent investigations (Bump et al, 1995; Kamens et al, 1995; Kayalar et al, 1996). Total protein extracts prepared from either mouse ovaries or HeLa cells were incubated with recombinant caspases or purified calpain and immunoblots were then performed. Analysis of fodrin indicated that caspase-3, caspase-1 and calpain, but not caspase-2, catalyzed cleavage of this protein (Figure 5). Calpain was originally proposed as the enzyme responsible for fodrin proteolysis during cell death (Martin et al, 1995). Although we could demonstrate calpainmediated fodrin cleavage in the cell-free assay, it is important to point out that consistent with previous data (Saido et al, 1993) the fragment produced by the actions of calpain was $150 \mathrm{kDa}$ (Figure 5B). During cell death, however, a $120 \mathrm{kDa}$ fragment of fodrin is generated (Figure 4) (Martin et al, 1995, 1996). This cleavage product generally predominates on immunoblots of proteins extracted from apoptotic cells (Figure 4) (Martin et al, $1995,1996)$, and is also the primary fragment produced specifically by the actions of caspase-3 (Figure 5). Therefore, as originally proposed (Saido et al, 1993), it may be that calpain is involved in fodrin turnover in the cell, albeit its function in this regard related to cell death remains an open question. However, these data do not rule out the involvement of calpain in other aspects of apoptosis execution as described previously (Squier et al, 1994). Of further note, caspase-1-mediated fodrin proteolysis similarly produced only the $150 \mathrm{kDa}$ fragment (Figure 5). Therefore, based on our data and recent observations that fodrin proteolysis is blocked by a specific peptide inhibitor of caspase-3 (DEVD; Martin et al, 1996), it may be that caspase-3 is a principal cytoplasmic protease responsible for complete fodrin breakdown during apoptosis.

Lastly, generation of the $41-42 \mathrm{kDa}$ actin doublet from the intact $42 \mathrm{kDa}$ cytoplasmic protein was produced by the action of either caspase-1 or caspase-3 in our cell-free assays (Figure 3 ). In the study by Kayalar and colleagues (1996), one immunoblot was presented that showed a minor actin cleavage product of $30 \mathrm{kDa}$ in PC12 cells induced to undergo apoptosis by serum starvation; however, the 41-42 kDa actin doublet produced by the actions of caspase- 1 or caspase- 3 in cell-free assays was not apparent. Nevertheless, it was proposed that cytoplasmic disruption and DNase-I activation during apoptosis result from caspase-1-mediated actin cleavage (Kayalar et al, 1996). In our experiments, extensive apoptosis induced in either follicles or HeLa cells occurred without cleavage of actin (Figure 2), despite the induction of caspase activity as evidenced by fodrin proteolysis in the same protein preparations (Figure 4). Although proteolysis of actin was not detected during apoptosis induced under diverse conditions in two different cell lineages, actin cleavage was produced with recombinant caspase-1 or caspase-3 in the cell-free assays (Figure 3 ).

\section{Conclusions}

The data presented extend earlier observations (Flaws et al, 1995a) by supporting a role for caspases and fodrin proteolysis in the cascade of events leading to granulosa cell apoptosis during ovarian follicular atresia. More importantly, however, these data reinforce the fact that observations made using cell-free approaches (actin cleavage by caspases) may not always be directly applicable to apoptosis in intact cells (actin not cleaved despite the fact caspases are active as evidenced by the inhibitory effects of zVAD and DEVD on apoptosis induction as well as by the 
occurrence of fodrin proteolysis). Preliminary findings demonstrate that in the case of PARP and DNA topoisomerase-I cleavage, two additional substrates for caspases, proteolysis of these proteins occurs with a different pattern of fragments produced, depending on if apoptotic or pathologic (necrotic) cell death ensued (Casiano and Tan, 1996). This would imply that different cell death mechanisms likely activate separate cohorts of proteases. Given that the kinetics of protein cleavage during apoptosis are different from the kinetics observed during primary necrosis, the specific cleavage products of the substrates described herein following incubation with recombinant enzymes should be carefully compared to those identified under particular paradigms of cell death. As exemplified by the discrepancy in results obtained with actin cleavage in cell-free versus intact cell systems presented herein, caution should be exercised in the interpretation of such findings from previous and future studies of apoptosis regulation.

\section{Materials and Methods}

\section{Reagents}

Human recombinant caspase-1 (ICE), caspase-2 (ICH-1) and caspase-3 (CPP32) were prepared as N-His-affinity-tagged proteins in Escherichia coli and activated prior to each experiment by dithiothreitol (DTT) treatment (Bump et al, 1995; Kamens et al, 1995). Cell-permeable fluoromethylketon (FMK) derivatives of the peptide inhibitors of caspases, ZVAD and ZDEVD (Thornberry et al, 1992; Wilson et al, 1994; Nicholson et al, 1995; Patel et al, 1996), were obtained from Enzyme Systems Products (Dublin, CA, USA). Equine CG (PMSG; $2180 \mathrm{IU} / \mathrm{mg}$ ) and calpain I ( $80 \mathrm{kDa}$ subunit purified from porcine erythrocytes; $120 \mathrm{U} / \mathrm{mg}$ ) were obtained from Calbiochem ( $\mathrm{La}$ Jolla, CA, USA), and cell culture medium and supplements were from Gibco-BRL (Gaithersberg, MD, USA). Anti-fodrin monoclonal antibody \#1622 was obtained from Chemicon (Temecula, CA, USA), and antiactin monoclonal antibody \#C4 was obtained from BoehringerMannheim (Indianapolis, IN, USA).

\section{Animals and tissues}

Immature female B6/C3 F1 mice, obtained from Charles-River (Wilmington, MA, USA) at 21 days of age, were given a single s.c. injection of $5 \mathrm{IU}$ of eCG to promote growth of a cohort of healthy antral follicles. Mice were euthanized $46 \mathrm{~h}$ later for collection of ovaries and dissection of follicles, as described (Tilly et al, 1992, 1995). In some experiments follicles were incubated for $24 \mathrm{~h}$ in the absence or presence $z V A D-F M K$ or zDEVD-FMK, and DNA integrity was then assessed (apoptosis). In other experiments follicles were incubated for $48 \mathrm{~h}$ without or with $1 \mathrm{mM}$ staurosporine (STSP; Sigma; St. Louis, MO, USA), after which follicles were processed for immunoblot analysis of fodrin and actin integrity in total protein extracts. All parameters for the follicle incubations were as detailed previously (Tilly et al, 1992, 1995). Recent studies have shown that rodent follicles incubated in vitro without trophic hormone support undergo a process that resembles atresia in vivo by all criteria examined and that the occurrence of apoptosis (defined by both morphological and biochemical criteria) is almost entirely restricted to granulosa cells (Tilly et al, 1992, 1995, 1996; Flaws et al, 1995a,b).

For additional comparisons to data obtained with mouse or human (HeLa) cells, in one set of experiments female Sprague-Dawley rats
(Charles-River) were injected with $10 \mathrm{IU}$ of eCG at 25 days of age and euthanized $46 \mathrm{~h}$ later for collection of the ovaries (Tilly et al, 1992 , 1995). Granulosa cells were harvested from the healthy cohort of gonadotropin-stimulated preovulatory follicles by selective needle puncture (Tilly et al, 1992, 1995). Total protein extracts were then prepared and used for cell-free proteolysis assays as described below.

All experimental protocols involving animals were reviewed and approved by the Massachusetts General Hospital Institutional Animal Care and Use Committee, and conformed with procedures outlined in the NIH Guide for the Care and Use of Laboratory Animals.

\section{Cell culture}

HeLa cells (ATCC CCL-2, Batch F-12477; American Type Culture Collection, Rockville, MD, USA) were grown and subcultured in Dulbecco's Modified Eagle's Medium supplemented with $10 \%$ fetal bovine serum. When approximately $80 \%$ confluence was reached, cells were either maintained (controls) or were induced to undergo apoptosis by UV-irradiation ( $120 \mathrm{~mJ}, 25 \mathrm{~s}$ ), by treatment with STSP $(0.5 \mu \mathrm{M})$ or C8-ceramide $(0.1 \mathrm{mM}$; Calbiochem $)$, or by serumstarvation. Cells were collected $16-18 \mathrm{~h}$ after experimental manipulation involving UV, STSP or C8-CER, or $120 \mathrm{~h}$ after serum starvation, and processed for immunoblot analysis of fodrin and actin integrity in total protein extracts. By morphology (condensation, pyknosis, detachment), greater than $85 \%$ of the HeLa cells were apoptotic after each experimental treatment (data not shown).

\section{Measurement of DNA integrity (oligonucleosome formation)}

Genomic DNA was extracted from follicles and 3 '-end-labeled with $\left[\alpha^{32} \mathrm{P}\right]$-ddATP (Amersham; Arlington Heights, IL, USA) using terminal transferase (Boehringer-Mannheim). Radiolabeled samples were resolved through $2 \%$ agarose gels, and the extent of apoptosis was assessed by autoradiography and $\beta$-counting of low MW $(<10 \mathrm{~kb})$ DNA fragments, as described (Tilly and Hsueh, 1993; Tilly, 1994).

\section{Cell-free proteolysis assays and immunoblot analysis}

Total protein was extracted from mouse or rat ovarian cells, or from HeLa cells, by homogenization in caspase activity buffer $(25 \mathrm{mM}$ HEPES, $10 \%$ glycerol, $10 \mathrm{mM}$ DTT). Samples were then boiled for $10 \mathrm{~min}$ to destroy endogenous protease activity, sonicated for $30 \mathrm{~s}$ to shear DNA, and centrifuged $\left(10000 \times g, 10 \mathrm{~min}, 4^{\circ} \mathrm{C}\right)$. Supernatants were collected for protein quantitation (Pierce MicroBCA; Rockford, IL, USA) and proteolytic digestion assays. Proteins $(200 \mu \mathrm{g})$ from each cellular preparation were incubated with $1 \mu \mathrm{g}$ of activated recombinant caspase (caspase-1, -2 or -3 ) or purified calpain for $2 \mathrm{~h}$ at $37^{\circ} \mathrm{C}$, and then resolved by SDS-PAGE through $8 \%$ (fodrin) or $15 \%$ (actin) gels. Resolved proteins were electrophoretically transferred to pure nitrocellulose membranes (Schleicher and Schuell; Keene, $\mathrm{NH}$, USA) and analyzed by immunoblot analysis for fodrin or actin cleavage, essentially as described (Flaws et al, 1995a), using the enhanced chemiluminescence system (Amersham).

\section{Data analysis and presentation}

Representative autoradiograms or immunoblots are presented for qualitative analysis of data obtained in at least three independent experiments. Combined data for oligonucleosome formation across replicate experiments were analyzed by ANOVA and Scheffe's F-test, with significance assigned at $P<0.05$. 


\section{Acknowledgements}

This study was supported by grants to JLT from the US National Institutes of Health (R01-HD34226, R01-AG12279, Office of Research on Women's Health). GIP is a Research Fellow supported in part by a grant from the Massachusetts General Hospital Fund for Medical Discovery. The work described herein is in partial fulfillment of the requirements for the Doctoral studies of DVM at the Boston University School of Medicine, Department of Pathology and Laboratory Medicine (Boston, Massachusetts, USA).

\section{References}

Alnemri ES, Livingston DJ, Nicholson DW, Salvesen G, Thornberry NA, Wong WW and Yuan J (1996) Human ICE/CED-3 protease nomenclature. Cell 87: 171

Bump N, Hackett M, Hugunin M, Seshagiri S, Brady K, Chen P, Ferenz C, Franklin S, Ghayhur T, Li P, Licari P, Mankovitch J, Shi L, Greenberg A, Miller LK and Wong WW (1995) Inhibition of ICE family proteases by baculovirus antiapoptotic protein p35. Science 269: 1885-1888

Cain K, Inayat-Hussain SH, Couet C and Cohen GM (1996) A cleavage-site-directed inhibitor of interleukin- $1 \beta$-converting enzyme-like proteases inhibits apoptosis in primary cultures of rat hepatocytes. Biochem. J. 314: 27-32

Casiano CA and Tan EM (1996) Apoptosis and necrosis are associated with selective but distinctively different cleavage of nuclear proteins. Mol. Biol. Cell (Supplement) 7: 33a

Casciola-Rosen L, Nicholson DW, Chong T, Rowan KR, Thornberry NA, Miller DK and Rosen A (1996) Apopain/CPP32 cleaves proteins that are essential for cellular repair: a fundamental principle of apoptotic death. J. Exp. Med. 183: 1957-1964

Ellis HM and Horvitz HR (1986) Genetic control of programmed cell death in the nematode C. elegans. Cell 44: 817-829

Flaws JA, Kugu K, Trbovich AM, DeSanti A, Tilly KI, Hirshfield AN and Tilly JL (1995a) Interleukin-1 $\beta$-converting enzyme-related proteases (IRPs) and mammalian cell death: dissociation of IRP-induced oligonucleosomal endonuclease activity from morphological apoptosis in granulosa cells of the ovarian follicle. Endocrinology 136: $5042-5053$

Flaws JA, DeSanti A, Tilly KI, Javid RO, Kugu K, Johnson AL, Hirshfield AN and Tilly $\mathrm{JL}$ (1995b) Vasoactive intestinal peptide-mediated suppression of apoptosis in the ovary: potential mechanisms of action and evidence of a conserved antiatretogenic role through evolution. Endocrinology 136: 4351-4359

Friedlander RM, Gagliardini V, Rotello RJ and Yuan J (1996) Functional role of interleukin-1 $\beta$ (IL-1 $\beta)$ in IL-1 $\beta$-converting enzyme-mediated apoptosis. J. Exp. Med. 184: 717-724

Jacobson MD, Weil M and Raff MC (1996) Role of Ced-3/ICE-family proteases in staurosporine-induced programmed cell death. J. Cell Biol. 133: 1041-1051

Kamens J, Paskind M, Hugunin M, Talanian R, Allen H, Banach D, Bump N, Hackett M, Johnston C, Li P, Mankovich J, Terranova M and Ghayur T (1995) Identification and cloning of $\mathrm{ICH}-2$, a novel member of the interleukin-1 $\beta$ converting enzyme family of cysteine proteases. J. Biol. Chem. 270: 1525015256

KayalarC, Örd T, Testa MP, Zhong L-T and Bredesen DE (1996) Cleavage of actin by interleukin-1 $\beta$-converting enzyme to reverse DNase linhibition. Proc. Natl. Acad. Sci. USA 93: $2234-2238$

Korsmeyer SJ (1995) Regulators of cell death. Trends in Genetics 11: 101-105

Kumar Sand Lavin MF (1996) The ICE family of cysteine proteases as effectors of cell death. Cell Death Differ. 3: 255-267

Kuida K, Lippke JA, Ku G, Harding MW, Livingston DJ, Su MS-S and Flavell RA (1995) Altered cytokine export and apoptosis in mice deficient in interleukin-1 $\beta$ converting enzyme. Science 267: 2000-2003

Li P, Allen H, Banerjee S, Franklin S, Herzog L, Johnston C, McDowell J, Paskin M, Rodman L, Salfeld J, Towne E, Tracey D, Wardwell S, Wei F-Y, Wong W, Kamen Rand Seshadri T (1995) Mice deficient in IL-1 $\beta$-converting enzyme are defective in production of mature IL-1 $\beta$ and resistant to endotoxic shock. Cell 80:401-411

Martin SJ and Green DR (1995) Protease activation during apoptosis: death by a thousand cuts? Cell 82: $349-352$

Martin SJ, O'Brien GA, Nishioka WK, McGahon AJ, Mahboubi A, Saido TC and Green DR (1995) Proteolysis of fodrin (non-erythroid spectrin) during apoptosis. J. Biol. Chem. 270: 6425-6428
Martin SJ, Amarante-Mendes GP, Shi L, Chuang T-H, Casiano CA, O'Brien GA, Fitzgerald P, Tan EM, Bokoch GM, Greenberg AH and Green DR (1996) The cytotoxic cell protease granzyme-B initiates apoptosis in a cell-free system by proteolytic processing and activation of the ICE/CED-3 family protease, CPP32, via a novel two-step mechanism. EMBO J. 15: 2407-2416

Mashima T, Naito M, Fujita N, Noguchi K and Tsururo T (1995) Identification of actin as a substrate of ICE and an ICE-like protease and involvement of an ICE-like protease but not ICE in VP-16-induced U937 apoptosis. Biochem. Biophys. Res. Commun. 217: 1185-1192

Nicholson DW, Ali A, Thornberry NA, Vaillancourt JP, Ding CK, Gallant M, Gareau Y, Griffin PR, Labelle M, Lazebnik Y, Munday NA, Raiu SM, Smulson ME, Yamin TT, Yu VL and Miller DK (1995) Identification and inhibition of the ICE/CED-3 protease necessary for mammalian apoptosis. Nature 376: 37-43

Patel T, Gores GJ and Kaufmann SH (1996) The role of proteases during apoptosis. FASEB J. 10:587-597

Saido TC, Yokota M, Nagao S, Yamaura I, Tani E, Tsuchiya T, Suzuki K and Kawashima S (1993) Spatial resolution of fodrin proteolysis in the postischemic brain. J. Biol. Chem. 268: 25239-25243

Squier MKT, Miller ACK, Malkinson AM and Cohen JJ (1994) Calpain activation in apoptosis. J. Cell. Physiol. 159: 229-237

Thompson C (1995) Apoptosis in the pathogenesis and treatment of disease. Science 267: 1456-1462

Thornberry NA, Bull HG, Calaycay JR, Chapman KT, Howard AD, Kostura MJ, Miller DK, Molineaux SM, Weidner JR, Aunins J, Elliston KO, Ayala JM, Casano FJ, Chin J, Ding GJ-F, Egger LA, Gaffney EP, Limjuco G, Palyha OC, Raju SM, Rolando AM, Salley JP, Yamin T-T, Lee TD, Shively JE, MacCross M, Mumford RA, Schmidt JA and Tocci MJ (1992) A novel heterodimeric cysteine protease is required for interleukin-1 $\beta$ processing in monocytes. Nature 356: 768-774

Tilly JL (1994) Use of the terminal transferase DNA labeling reaction for the biochemical and in situ analysis of apoptosis. In Cell biology: a laboratory handbook, in Celis JE, ed. (San Diego: Academic Press) pp. 330-337

Tilly JL (1996) Apoptosis and ovarian function. Rev. Reprod. 1: 162-172

Tilly JL and Hsueh AJW (1993) Microscale autoradiographic method for the qualitative and quantitative analysis of apoptotic DNA fragmentation. J. Cell Physiol. 154: 519-526

Tilly JL and Ratts VS (1996) Biological and clinical importance of ovarian cell death. Contemp. Obstet. Gynecol. 41: 59-86

Tilly JL, Billig H, Kowalski KI and Hsueh AJW (1992) Epidermal growth factor and basic fibroblast growth factor suppress the spontaneous onset of apoptosis in cultured rat ovarian granulosa cells and follicles by a tyrosine kinase-dependent mechanism. Mol. Endocrinol. 6: 1942-1950

Tilly JL, Tilly KI, Kenton ML and Johnson AL (1995) Expression of members of the bcl2 gene famliy in the immature rat ovary: equine chorionic gonadotrophinmediated inhibition of apoptosis is associated with decreased bax and constitutive $b c l-2$ and $b c l-x_{\text {long }}$ messenger ribonucleic acid levels. Endocrinology 136:232-241

Tilly JL, Flaws JA, DeSanti AM, Hughes FM Jr, Tilly KI, Maravei DV, Trbovich AM, Cidlowski JA and Hirshfield AN (1996) Biochemical and morphological investigation of apoptosis and atresia in rat ovarian antral follicles incubated in vitro. Biol. Reprod. 54 (Supplement 1):87

Tilly JL, Tilly KI and Perez GI (1997) The genes of cell death and cellular susceptibility to apoptosis in the ovary: a hypothesis. Cell Death Differ. 4: 180-187

Wang L, Miura M, Bergeron L, Zhu H and Yuan J (1994) Ich-1, an Ice/ced-3-related gene, encodes both positive and negative regulators of programmed cell death. Cell 78: $739-750$

Weil M, Jacobson MD, Coles HSR, Davies TJ, Gardener RL, Raff KD and Raff MC (1996) Constitutive expression of the machinery for programmed cell death. J. Cell Biol. 133: 1053-1059

Wilson KP, Black JF, Thomson JA, Kim EE, Griffith JP, Navia MA, Murcko MA, Chambers SP, Aldape RA, Raybuck SA and Livingston DJ (1994) Structure and mechanism of interleukin- $1 \beta$ converting enzyme. Nature 370: 270-275

Wyllie AH (1995) The genetic regulation of apoptosis. Curr. Opin. Genet. Develop. 5: $97-104$

Xue D, Shaham S and Horvitz HR (1996) The Caenorhabditis elegans cell-death protein CED-3 is a cysteine protease with substrate specificities similar to those of the human CPP32 protease. Genes Develop. 10: 1073-1083

Yuan J, Shaham S, Ledoux S, Ellis H and Horvitz HR (1993) The C. elegans cell death gene ced-3 encodes a protein similar to mammalian interleukin-1 $\beta$-converting enzyme. Cell 75: 641-652 